\title{
Elephants in Aceh, Sumatra
}

\section{S. Poniran}

Elephants still occur in the large Indonesian island of Sumatra, but mostly in small groups of up to seven animals. In the northern province of Aceh the author, after a two-year study, estimates that numbers are now less than a third of what they were 35 years ago. He sees the best hope for their future in scientific management geared to culling the wild populations for working animals, as is done in India.

There must have been a rich population of wild elephants in Aceh, in north Sumatra, in the 17th century to supply the large numbers of tamed animals mentioned by various writers (7). A. de Beaulieu, writing in 1621, speaks of 900; Peter Mundy describes 150 at a tournament in 1638, and Nicolaas de Graaf writes of 260 at the funeral ceremonies of Sultan Iskandar Thani in 1641. Tamed elephants came from the wild population, as they still do in India, Ceylon, Burma and Thailand; the catching and taming methods used in Aceh are described by 17 th-century travellers and observers. In 1724 Valentijn can still write of great numbers of tamed animalsapproximately 1000 - but by 1839 Ritter reports the end of the keeping of tamed animals by the Acehnese kings, princes and sultans. It may be true that the keeping of too great numbers in captivity or semi-captivity drained the wild populations, but scientific management of tamed and wild elephants together could lead to stable numbers in both populations.

In my two-year study of wild elephants in Aceh, I used C.R. Carpenter's survey methods (3), thus making possible an approximate . comparison with the conditions he found in 1937/38. On several occasions I was able to discuss elephant problems with F. W. Rappard, who had studied elephants in south Sumatra and on the mainland of south-east Asia $(9,10)$, and I wish to thank him for his co-operation in publishing my findings. Recently also we had the opportunity to confer on elephants with John H. Blower, FAO Wildlife Conservation Adviser in Nepal, when he visited Medan, north Sumatra and Aceh.

Richard Carrington's popular monograph on elephants (4) treated Sumatra only superficially, and his bibliography omitted F.C. van Heurn's 1929 monograph (7), which even at that date listed 61 relevant titles, and also two studies on elephant population management from India which $I$ have included $(1,2)$.

Elephants still occur on Sumatra in several types of wild country, from Aceh in the north to Lampung (Lampong) and Bengkulu (Bencoolen) provinces in the south, mostly in groups of 2-7. Each province has its stable groups of two to seven animals, moving on regular routes, sometimes led by a great bull. Large bulls sometimes wander alone, both in the primary and secondary forests and also in

S. Poniran is Head of the Nature Protection and Wildlife Management Service Section in the Special Province of Aceh, Indonesia. 


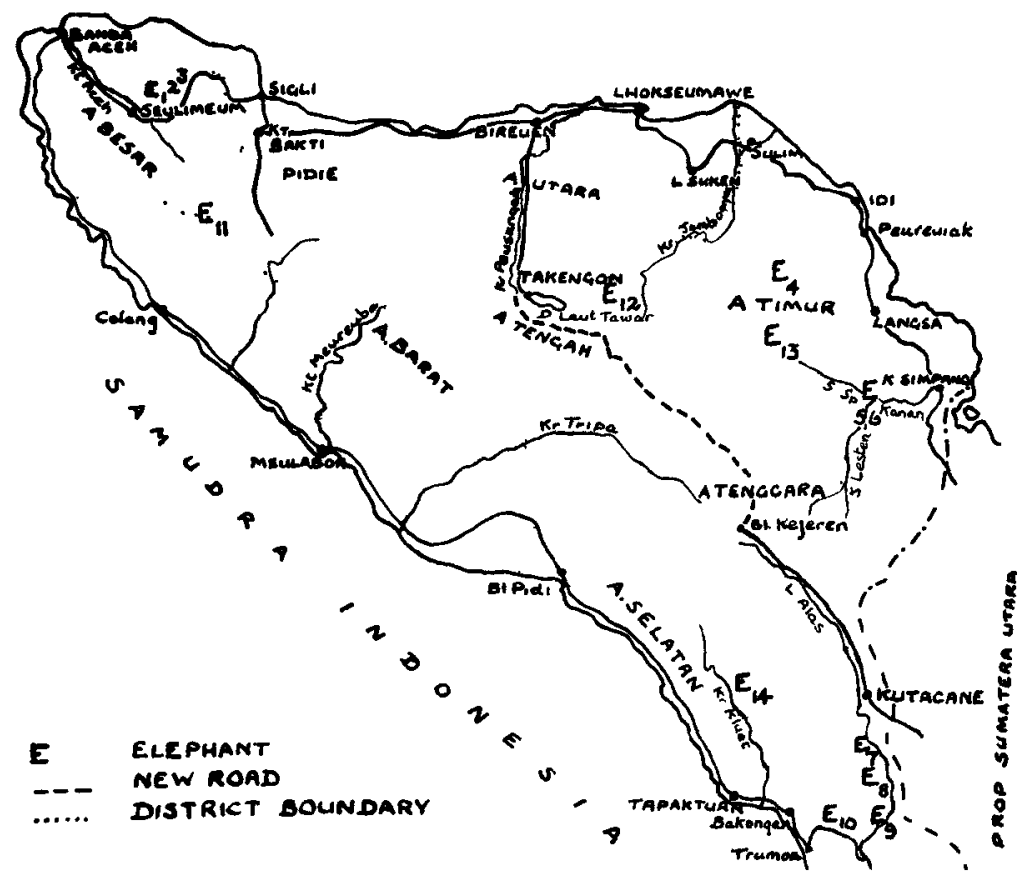

cultivated fields on the forest edges. The groups trek through mountains and forests to certain places, and return along the same tracks, keeping as near to the level as possible, and often using the same tracks year after year. They are not deterred if parts of their tracks have been converted to wet ricefields (sawah) or other cultivation (ladang), and in certain fields reports of elephants are frequent, for instance near the river Kompas (Lawe Kompas) and the Lawe Sipurgur in the district Aceh Tenggara (south-east Aceh).

Elephants eat a great variety of wild foods-herbaceous plants, young leaves, roots and lianas, young rattan palms or the tops of these climbing palms, the bark of certain tree saplings, bamboo shoots and especially young leaves of the smaller bamboo species, reed grasses, and whole wild bananas, including the soft stems. When they come to an established ladang or sawah they will eat sugar cane, rice, fruits of the field, young cocos leaves and the growing point of the cocos palm as well banana, papaya and so on, and they are fond of young plantations. Farmers visited by an elephant find themselves all of a sudden in big trouble, and a visit from a whole group leads to reports that elephants are 'running amok' or 'going berserk'.

According to my calculations in Aceh an elephant may eat up to 300 kilograms of green stuff each day-made up of perhaps three to five ripe durian fruits or up to 30 ripe mangoes, with some young coconuts and bunches of bananas, and any other choice morsels they may find. They tear down branches to get the top leaves, and will destroy a whole tree to get the bark and roots, after which, if undisturbed, they may stay a time in the same place. The larger animals leave droppings as big as coconuts everywhere along their tracks; urine they void along rivers and brooks or near swamps when drinking. I calculate they drink $20-50$ litres a day. 


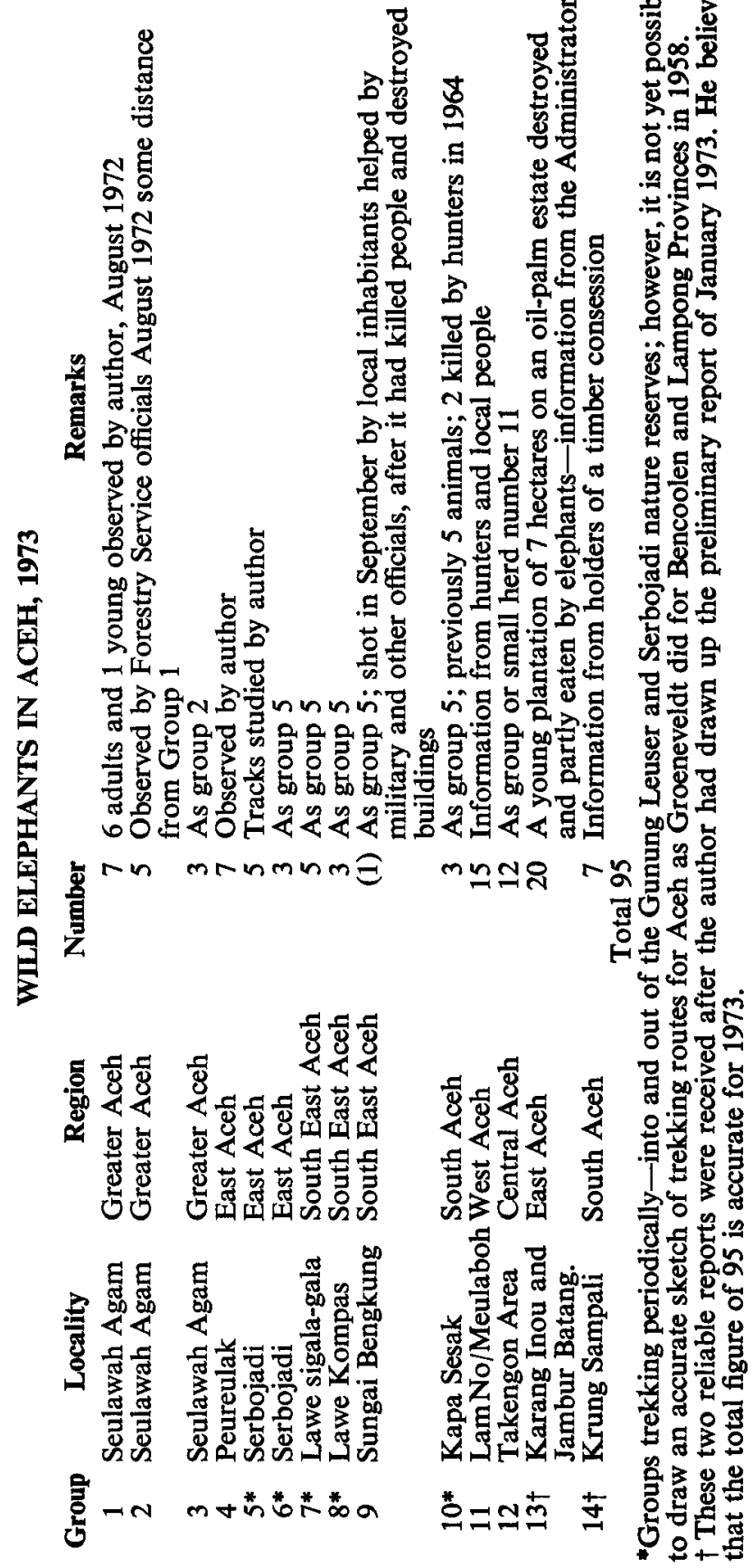




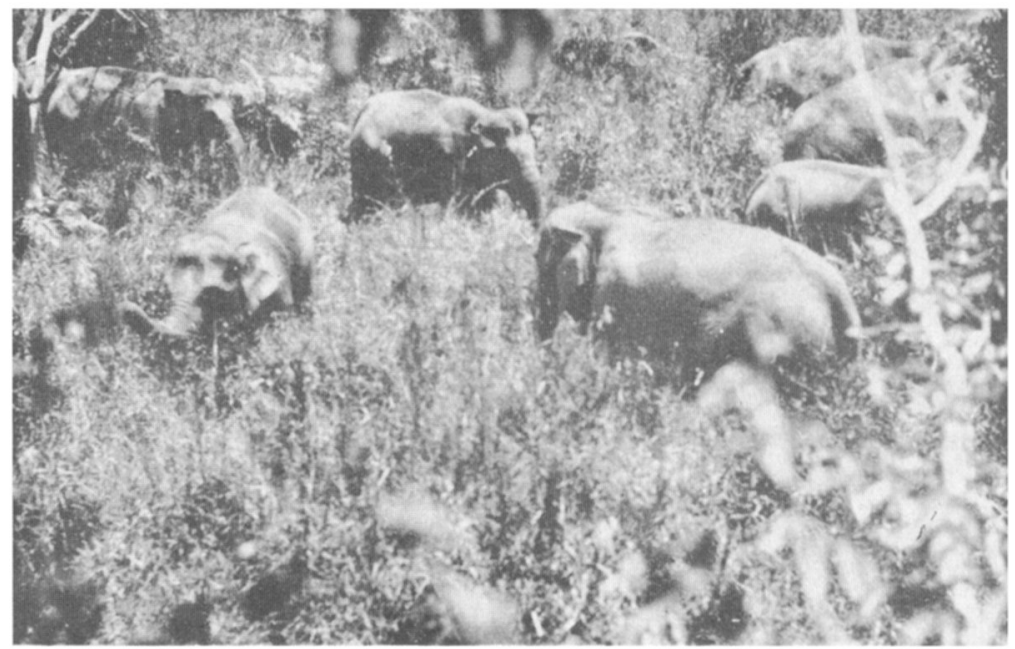

\section{Distribution}

Distribution is summarised in the table opposite. Adults tracks range in size from 35 to $44 \mathrm{cms}$ - the largest was found near the warm water springs of Lawe Kompas in the Gunung Leuser National Park. The tracks of young animals ranged from $18-22 \mathrm{cms}$. Calculated on the basis of track/height relations in Sumatra, the animal near Lawe Kompas must have been more than three metres tall, and mud traces on leaning and overhanging bamboos show that heights of 2.2 and $2.9 \mathrm{~m}$. are a common occurrence. Group number 7 drinks at the warm water springs at Uning Si Gugur, and bathes there; number 8 does the same near Lawe Kompas, and near Nodi they also eat a special soil in the form of mud. This mud-eating could be for health reasons.

It is no easy matter to compare our findings with Carpenter's survey $\mathbf{3 5}$ years ago, as he could not obtain exact numbers. In the 1930 s an average Sumatran herd numbered about 20 animals, a large one about 60 . Carpenter reported (chapter 5 of his survey) several average-sized herds along Peureulak and Simpang Kanan rivers, which must mean at least 60 animals; many elephants in the high mountains toward Kuta Radja, now Banda Aceh, from Takengon, which means at least 30; a large herd near kilometre-stone 330 on the west coast not far from Blang Pidië-at least 50; the largest number -i.e. at least 60-in the region between Lam No and Sigli and between Lam No and Tangse, from where a herd annually passed the 'Gold Mountain Forest' (now Seulawah Agam); and 'rather large herds' (at least 120 animals) in the Leuser complex. This gives a total of more than 300 elephants in the wilds of Aceh.

Today numbers have shrunk to less than a third of this figure. There are no longer any large herds in Aceh, and the only 'average sized herd' is in East Aceh. There are small herds-groups or very small groups, remnants of once greater wild elephant communities. Some groups are so small and isolated that it is questionable whether propagation is still possible, so that even with full protection, elephants could disappear completely in regions where they still occur. Many elephants will be shot before they reach maximal age, despite protection by law. 


\section{Population Management}

Scientific management of wildlife populations has to be based on biological and other surveys, so the internal and external relations of each elephant group must be studied. The dwindling elephant population in Aceh has to be managed, otherwise, within a few years, it will be a thing of the past. Where groups are too small and too isolated to survive, capture for taming as working elephants should be tried. Rappard's proposition in 1946 to use elephants for timber hauling is now impracticable and would require too many animals, but in some Sumatran village communities the keeping of elephants would still fit into their structure.

Browne and Anselm, quoted by Rappard (10), practised methods of managing wild elephants in combination with captive elephants. They described capture methods used in southern India and applicable to conditions in Sumatra, using camouflaged pitfalls with a thick $(1.5 \mathrm{~m})$ layer of grasses and bushes to break the elephant's fall so that it is uninjured. Animals that are too old or too young can be returned to the jungle; the rest can be trained in six to eight months for all kinds of jungle work. Eventually these methods could be used also for transporting wild elephants to places where they would be less nuisance to farmers.

Sumatra too could use elephants in nature reserves and similar areas as tourist attractions; such centres would need only half-a dozen or fewer elephants. John Blower wrote, 'I think the possibility of domesticating elephant in north Sumatra is well worth looking into. We use elephant a great deal in Nepal Terai, where they are of enormous value both for surveys, patrolling and other work in the forest but also as a tourist attraction. They of course provide excellent means for visitors to view wild life in jungle areas, at the same time causing minimum disturbance and providing the visitors with a novel experience which they enjoy tremendously.'

\section{References}

1. ANSELM, S.G.M. 1930. Capturing Elephants in Travancore. Indian Forester 61: 447-451.

2. BROWNE, R.S. 1930. Capturing and training of elephants by the Madras Forest Department. Indian Forester 61: 266-272.

3. CARPENTER, C.R. 1938. A survey of wild life conditions in Atjeh, North Sumatra. Communications: Netherlands Commission for International Nature Protection 12: V, 60-62.

4. CARRINGTON, R. Elephants. 1958.

5. DIEBEN, C. 1946. Olifanten als sleepvee. Tectona 36: 379.

6. GROENEVELDT, W. 1938. Een overzicht van de vaste trekwegen van olifanten in Zuid-Sumatra alsmede eenige gegevens over rhinocerossen. Communications: Netherlands Commission for International Nature Protection 12: 73-112.

7. V. HEURN, JHR. F.C. 1929. De olifanten van Sumatra.

8. PIETERS, D. 1932. Ondervindingen en waarnemingen omtrent olifanten in Sumatra. De Tropische Natuur 21: 57-59.

9. RAPPARD, F.W. 1935. Iets over olifanten. Tectona 28: 927-932.

10. RAPPARD, F.W. 1946. Olifanten als sleepvee. (Elephants as working animals). Tectona 36: 274-281.

The photograph by $\mathrm{D}$. Pieters was published in De Tropische Natuur, April 1932, Netherlands Indies. 